\title{
PERBEDAAN KEBERADAAN LARVA AEDES AEGYPTI ANTARA \\ RUMAH BUMANTIK DAN NON BUMANTIK DI WILAYAH KERJA \\ PUSKESMAS PUCANG SEWU SURABAYA 2018
}

Liana Dewi Wahyuni, Winarko, Setiawan

\begin{abstract}
ABSTRAK
Tiga faktor yang berkontribusi dalam terjadinya penyakit DBD secara epidemiologi yaitu Host, agent dan environment. Keterlibatan masyarakat dalam PSN diperlukan, diantaranya Bumantik yang bertugas dalam pemeriksaan jentik. Wilayah kerja Puskesmas Pucang Sewu merupakan daerah endemis DBD dalam 3 tahun berturut-turut. Hasil pengamatan beberapa rumah di Kelurahan Baratajaya ditemukan larva Aedes aegypti melalui perhitungan ABJ. Penelitian ini bertujuan mengetahui perbedaan keberadaan larva Aedes aegypti antara rumah bumantik dan non bumantik di Wilayah Kerja Puskesmas Pucang Sewu Surabaya

Penelitian ini termasuk jenis penelitian observasional dengan pendekatan cross sectional. Teknik pengambilan sampel menggunakan quota sampling dengan sampel masing - masing 30 rumah bumantik dan rumah non bumantik. Analisis data penelitian menggunakan uji Independent T Test dan Chi square.

Hasil penelitian menunjukkan bahwa terdapat perbedaan keberadaan larva Aedes aegypti antara bumantik dan non bumantik dilihat dari nilai $p=0,229(p>0,05)$ keberadaan larva positif lebih besar terdapat pada bumantik dari pada non bumantik.

Disarankan bumantik dapat meningkatkan kesadaran dalam kegiatan PSN sehingga pengetahuan dan sikap yang baik dapat sejalan dengan tindakan yang baik pula.
\end{abstract}

Kata Kunci : Bumantik, Non - Bumantik, Jentik

\section{PENDAHULUAN}

Secara epidemiologi ada tiga faktor yang sering berkontribusi dalam terjadinya penyakit Demam Berdarah Dengue yaitu manusia, virus dengue, dan lingkungan. Perlunya keterlibatan masyarakat dalam pemberantasan sarang nyamuk termasuk peran bumantik. (Tri, 2008)
Pemberdayaan masyarakat melalui jumantik, diharapkan masyarakat dapat secara bersamasama melakukan pencegahan sebelum terjadi penularan penyakit DBD secara mandiri yakni dari, oleh, dan untuk masyarakat (Arta, Ferry dan Eka., 2015) 
Tempat perindukan nyamuk merupakan salah satu aspek bionomik nyamuk Aedes aegypti yang dapat dijadikan kunci dalam pengendalian vektor melalui program PSN dengan teknik surveilans vektor. Keberhasilan kegiatan kegiatan PSN dapat diukur dengan Angka Bebas Jentik (ABJ) (Siska dan Widya, 2017).

Berdasarkan hasil informasi yang didapat telah dilakukan pelatihan terhadap bumantik tentang peningkatan pengetahuan dan ketrampilanbumantik dalam mengidentifikasi bionomik vektor DBD di wilayah kerja Puskesmas Pucang Sewu pada bulan Mei 2016.

Penelitian bertujuan untuk membandingkan ABJ rata - rata Bumantik dan non-Bumantik serta menganalisis pengaruh PSN terhadap keberadaan larva Aedes aegypti.

\section{METODE PENELITIAN}

Penelitian ini merupakan jenis penelitian observasional dengan pendekatan cross sectional. Teknik pengambilan sampel menggunakan metode non probability sampling dengan teknik quota sampling.

Pengambilan sampel pada non bumantik didasarkan pada karakteristik rumah yang sama dengan sampel rumah bumantik dan dipilih yang berdekatan dari sampel rumah bumantik. Sampel diambil 30 bumantik dan 30 non - bumantik di Wilayah Keja Puskesmas Pucang Sewu Surabaya. Analisis data menggunakan Independen T Test dan Chi square.

\section{HASIL PENELITIAN DAN PEMBAHASAN}

1. Distribusi Frekuensi Pengetahuan Bumantik Dan Non Bumantik Terkait Bionomik Vektor DBD

Tabel 1

DISTRIBUSI FREKUENSI PENGETAHUAN BUMANTIK DAN NON BUMANTIK DI WILAYAH KERJA PUSKESMAS PUCANG SEWU KOTA SURABAYA TAHUN 2018

\begin{tabular}{ccccc}
\hline Pengetahuan & \multicolumn{2}{c}{ Jumlah } & \multicolumn{2}{c}{ Persentase } \\
\cline { 2 - 5 } & Bumantik & $\begin{array}{c}\text { Non } \\
\text { Bumantik }\end{array}$ & Bumantik & $\begin{array}{c}\text { Non } \\
\text { Bumantik }\end{array}$ \\
\hline Baik & 28 & 21 & $93,3 \%$ & $70,0 \%$ \\
\hline Cukup & 2 & 7 & $6,7 \%$ & $23,3 \%$ \\
\hline Kurang & 0 & 2 & $0 \%$ & $6,7 \%$ \\
\hline
\end{tabular}

Tabel 1 menyajikan bahwa baik sedangkan engetahuan non pengetahuan bumantik 93,3\% kategori bumantik berkategori baik hanya 
menunjukkan 70\%. Dugaan ini bahwa terjadi peningkatan disebabkan adanya pelatihan yang pengetahuan sesudah dilakukan dilakukan bumantik sebelumnya. Hasil penyuluhan yaitu sebesar 50,76\% penelitian ini sejalan dengan menjadi $78,33 \%$. penelitian Hidayatul dan Efa (2018),

2. Distribusi Frekuensi Sikap Bumantik Dan Non Bumantik Terkait Bionomik vektor DBD

Tabel 2

DISTRIBUSI FREKUENSI SIKAP BUMANTIK DAN NON BUMANTIK DI WILAYAH KERJA PUSKESMAS PUCANG SEWU KOTA SURABAYA TAHUN 2018

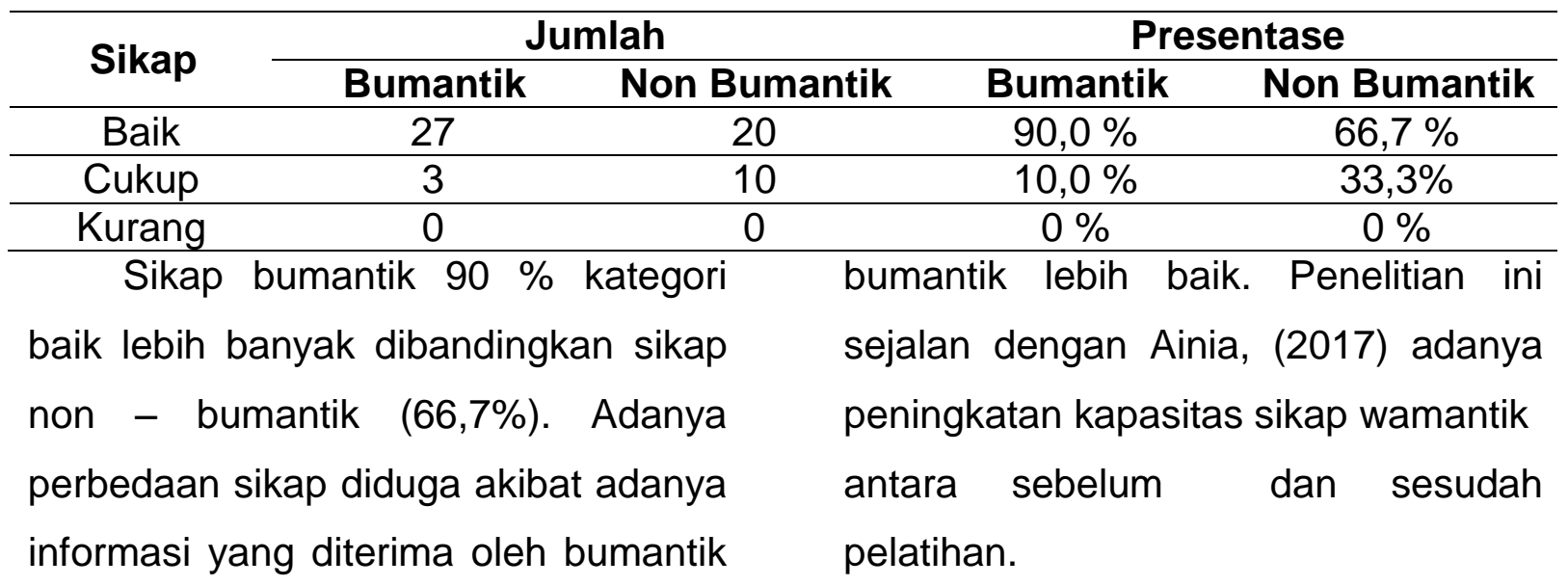
saat pelatihan sehingga sikap

3. Distribusi Frekuensi Tindakan Bumantik Dan Non Bumantik Terkait Bionomik vektor DBD

Tabel 3

DISTRIBUSI FREKUENSI TINDAKAN BUMANTIK DAN NON BUMANTIK DI WILAYAH KERJA PUSKESMAS PUCANG SEWU KOTA SURABAYA TAHUN 2018

\begin{tabular}{ccccc}
\hline Tindakan & \multicolumn{2}{c}{ Jumlah } & \multicolumn{2}{c}{ Persentase } \\
\cline { 2 - 5 } & Bumantik & $\begin{array}{c}\text { Non } \\
\text { Bumantik }\end{array}$ & Bumantik & $\begin{array}{c}\text { Non } \\
\text { Bumantik }\end{array}$ \\
\hline Baik & 29 & 27 & $96,7 \%$ & $90 \%$ \\
\hline Cukup & 1 & 3 & $3 \%$ & $10 \%$ \\
\hline Kurang & 0 & 0 & $0 \%$ & $0 \%$ \\
\hline
\end{tabular}

Tindakan tentang bionomik vektor penelitian ini sejalan dengan penelitian DBD bumantik 96,7 \% kategori baik Ainia, (2017) bahwa adanya peningkatan dibanding dengan tindakan non - kapasitas pengetahuan, sikap dan bumantik yaitu sebesar 90\%. Hasil 
keterampilan wamantik antara sebelum dan sesudah pelatihan.

4. Nilai ABJ Pada Rumah Bumantik Dan Non - Bumantik Di Wilayah Kerja Puskesmas Pucang Sewu

Tabel 4

NILAI ABJ PADA RUMAH BUMANTIK DAN NON BUMANTIK

DI WILAYAH KERJA PUSKESMAS PUCANG SEWU

KOTA SURABAYA TAHUN 2018

\begin{tabular}{ccc}
\hline $\begin{array}{c}\text { Keberadaan } \\
\text { Jentik }\end{array}$ & Bumantik & Non - Bumantik \\
\hline Positif & 9 rumah & 5 rumah \\
\hline Negatif & 21 rumah & 25 rumah \\
\hline ABJ & $70 \%$ & $83,3 \%$
\end{tabular}

Nilai ABJ bumantik yang responden. Hasil penelitian ini sejalan

didapatkan yaitu sebesar 70\% lebih dengan penelitian Ririn dkk (2013)

rendah dibandingkan dengan nilai $A B J$ bahwa adanya hubungan bermakna

non bumantik yaitu sebesar 83,3\%. kegiatan PSN, menutup dan menguras

Hal ini dapat terjadi karena kurang tempat penampungan air, memakai

optimalnya dalam melakukan lotion anti nyamuk dan menabur bubuk

pemberantasan sarang nyamuk (PSN) abate.

dan kebiasaan atau perilaku

5. Kegiatan Pemberantasan Sarang Nyamuk (PSN) Aedes aegypti

Tabel 5

KEGIATAN PSN AEDES AEGYPTI PADA RUMAH BUMANTIK DI WILAYAH KERJA PUSKESMAS PUCANG SEWU KOTA SURABAYA TAHUN 2018

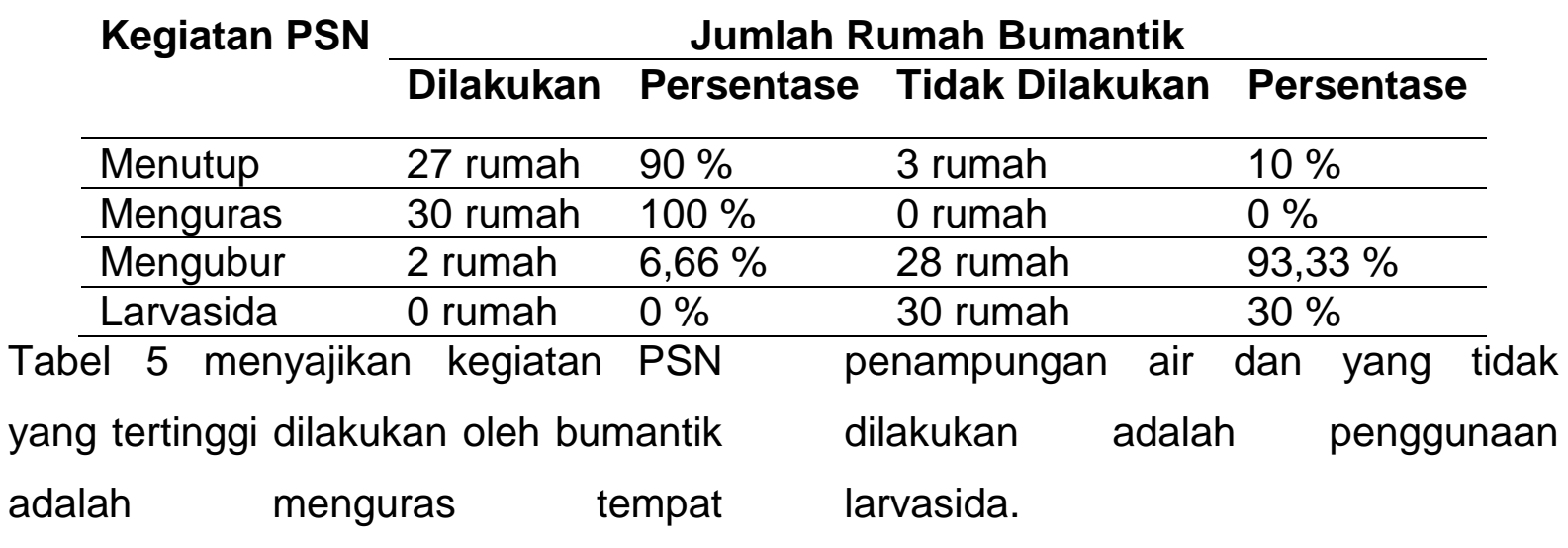

Tabel 6

KEGIATAN PSN AEDES AEGYPTI PADA RUMAH NON BUMANTIK

DI WIL. KERJA PUSKESMAS PUCANG SEWU KOTA SURABAYA TAHUN 2018

\section{Jumlah Rumah Non Bumantik}




\begin{tabular}{lcccc}
\hline Kegiatan PSN & Dilakukan & Persentase & Tidak Dilakukan & Persentase \\
\hline Menutup & 29 rumah & $96,66 \%$ & 1 rumah & $3,33 \%$ \\
\hline Menguras & 30 rumah & $100 \%$ & 0 rumah & $0 \%$ \\
\hline Mengubur & 4 rumah & $13,33 \%$ & 26 rumah & $86,66 \%$ \\
\hline Larvasida & 0 rumah & $0 \%$ & 30 rumah & $100 \%$ \\
\hline
\end{tabular}

Kegiatan PSN yang dilakukan oleh seluruh non bumantik adalah menguras tempat penampungan air dan yang tidak dilakukan adalah penggunaan larvasida. PSN menutup tempat penampungan air sebesar $96,66 \%$ dan mengubur barang bekas sebesar $13,33 \%$.

6. Perbedaan keberadaan larva Aedes aegypti

Tabel 7

PERBEDAAN KEBERADAAN LARVA AEDES AEGYPTI RUMAH BUMANTIK DAN NON - BUMANTIK DI WIL. KERJA PUSKESMAS PUCANG SEWU TAHUN 2018

\begin{tabular}{lcccccc}
\hline Keberadaan Jentik & \multicolumn{2}{c}{ Positif } & \multicolumn{2}{c}{ Negatif } & \multicolumn{2}{c}{ Jumlah } \\
\cline { 2 - 7 } & $\mathrm{n}$ & $\%$ & $\mathrm{~N}$ & $\%$ & $\mathrm{n}$ & $\%$ \\
\hline Bumantik & 9 & 30 & 21 & 70 & 30 & 100 \\
\hline Non Bumantik & 5 & 16,66 & 25 & 83,33 & 30 & 100 \\
\hline Keberadaan jentik & pada & rumah & \multicolumn{2}{c}{ mewujudkan sikap yang baik menjadi } \\
responden bumantik lebih besar yaitu & \multicolumn{2}{c}{ suatu perbuatan yang baik perlu } \\
$30 \% \quad$ dibandingkan & rumah non & adanya kebiasaan yang dilakukan \\
bumantik yaitu sebesar & 16,66\%. Untuk & \multicolumn{2}{l}{ secara berulang. }
\end{tabular}

7. Pengaruh PSN terhadap Keberadaan Larva Aedes aegypti

Tabel 8

PENGARUH PSN TERHADAP KEBERADAAN LARVA A. AEGYPTY PADA RUMAH BUMANTIK DAN NON BUMANTIK DI WIL. KERJAPUSKESMAS PUCANG SEWU KOTA SURABAYA TAHUN 2018

\begin{tabular}{|c|c|c|c|c|c|c|c|c|c|c|c|c|}
\hline \multirow{3}{*}{$\begin{array}{c}\text { Kegiatan } \\
\text { PSN }\end{array}$} & \multicolumn{6}{|c|}{ Bumantik } & \multicolumn{6}{|c|}{ Non Bumantik } \\
\hline & \multicolumn{2}{|c|}{ Positif } & \multicolumn{2}{|c|}{ Negatif } & \multicolumn{2}{|c|}{ Jumlah } & \multicolumn{2}{|c|}{ Positif } & \multicolumn{2}{|c|}{ Negatif } & \multicolumn{2}{|c|}{ Jumlah } \\
\hline & $\mathbf{n}$ & $\%$ & $n$ & $\%$ & $\mathbf{n}$ & $\%$ & $\mathbf{n}$ & $\%$ & $\mathbf{n}$ & $\%$ & $\mathbf{n}$ & $\%$ \\
\hline Baik & 2 & 26,66 & 17 & 56,66 & 24 & 80 & 4 & 13,33 & 19 & 63,33 & 23 & 76,66 \\
\hline Kurang & 7 & 6,66 & 4 & 13,33 & 6 & 20 & 1 & 3,33 & 6 & 20 & 7 & 23,33 \\
\hline Nilai ABJ & & & & & & & & & & $3 \%$ & & \\
\hline
\end{tabular}

Adanya pengaruh PSN yang dilakukan oleh bumantik dan non bumantik terhadap keberadaan larva Aedes aegypti. Analisis Chi square didapatkan nilai $p=0,002(p>0,05)$.
Responden non bumantik didapatkan nilai $p=0,015(p>0,05)$ yang berarti terdapat pengaruh kegiatan PSN terhadap keberadaan larva Aedes aegypti. Hasil penelitian ini sejalan 
dengan Nahdah (2013) bahwa terdapat hubungan antara perilaku 3M plus dengan keberadaan densitas larva Aedes aegypti di Kelurahan Birobuli Selatan Kota Palu.

\section{KESIMPULAN}

Ada perbedaan pengetahuan, sikap, tindakan antara bumantik dan non bumantik terkait bionomik vektor DBD. Nilai ABJ pada non bumantik lebih tinggi daripada ABJ bumantik. Terdapat perbedaan keberadaan larva Aedes aegypti, keberadaan larva positif lebih besar terdapat pada bumantik dari pada non bumantik. Adanya pengaruh PSN yang dilakukan oleh bumantik dan non bumantik terhadap keberadaan larva Aedes aegypti.

\section{SARAN}

Memberi pelatihan dan pemantauan berkala setelah pelatihan. Melaksanakan kegiatan PSN yang belum terlaksana, pengurasan yang benar minimal $1-2$ kali dalam seminggu.

\section{DAFTAR PUSTAKA}

1. Aqida, Ainia Nurul. 2017. Pengaruh Pelatihan Siswa Pemantau Jentik Terhadap Pengetahuan, Sikap Dan
Keterampilan Di Sekolah Dasar Kecamatan Pamulang.

2. Arsula, Siska Yunita dan Widya Hary Cahyati. 2017. Pembentukan Mawas Demam Berdarah Dengue (Dbd) Terhadap Angka Bebas Jentik (Abj). Jurnal Care Vol .5, No.1.

3. Nahdah dkk. 2013. Hubungan Perilaku 3m Plus Dengan Densitas Larva Aedes aegypti Di Kelurahan Birobuli Selatan Kota Palu Sulawesi Tengah.

4. Nugroho, Efa dan Rubandiyah, Hidayatul Issri. 2018. Pembentukan Kader Jumantik Sebagai Upaya Peningkatan Pengetahuan Siswa di Sekolah Dasar. Higeia Journal of Public Health Research and Development, 2 (2), 216-226.

5. Rini, Arta Sapta., Efendi, Ferry dan Eka Misbahatul M Has. 2015. Hubungan Pemberdayaan Ibu Pemantau Jentik dengan indikator keberhasilan pemberantasan sarang nyamuk (PSN) di Kelurahan Wonokromo Surabaya. Universitas Airlangga: Surabaya www.journal.unair.ac.id/filerPDF/.

8 Januari 2018

6. Sumantri, Ririn. Petrus Hasibuan dan Virhan Novianry. 2013. Hubungan Pemberantasa Sarang 
Nyamuk (PSN) Dan Kebiasaan

Keluarga Dengan Kejadian

Demam Berdarah Dengue (DBD)

Di Kota Pontianak

7. Wijayanti, Tri. Balaba: Jurnal Litbang Pengendalian Penyakit Bersumber Binatang Banjarnegara.

BALABA, Ed.007, no. 02, Des $2008: 18$. 